\title{
Social Pedagogy as a Scientific DisCIPLINE - A BRANCH OF ACADEMic STUdies ANd a Field of Professional Practice
}

\author{
Pedagogia Social como uma Disciplina Científica - \\ uM Ramo de Estudos ACAdÊMICOS E UM CAMPo DE \\ Prática Profissional
}

\author{
Juha Hämäläinen \\ University of Eastern Finland \\ Department of Social Science. Kuopio, Finlândia. \\ ORCID: https://orcid.org/0000-0002-9834-1529 \\ juha.hamalainen@uef.fi
}

\begin{abstract}
Resumo: Este artigo baseia-se em produçóes que tratam de aspectos da pedagogia social analisados por Hämäläinen, individual e coletivamente, como a ambiguidade conceitual da pedagogia social, a natureza da pedagogia social como disciplina acadêmica, a orientação pedagógica social no trabalho social e no trabalho com jovens, as formas de usar o conceito na Alemanha e na Finlândia, bem como a visão geral do campo, incluindo considerações semânticas e históricas. São empregadas ainda outras fontes de informação, especialmente materiais em que tradiçóes nacionais de pedagogia social e debates sobre sua natureza são introduzidos, comparados, decodificados e clarificados Metodologicamente este trabalho é baseado, principalmente, na análise de conceitos históricos.
\end{abstract}

Palavras-chave: Educação Social. Finlândia. Pedagogia Social. Trabalho Social.

Aвstract: This article is based on productions dealing with aspects of social pedagogy analyzed by Hämäläinen, individually and collectively, such as the conceptual ambiguity of social pedagogy, the nature of social pedagogy as an academic discipline, social pedagogical guidance in social work and work with young people, ways of using the concept in Germany and Finland, as well as the field overview, including semantic and historical considerations. Other sources of information are also used, especially materials in which national traditions of social pedagogy and debates about their nature are introduced, compared, decoded and clarified. Methodologically, this work is based mainly on the analysis of historical concepts.

Keywords: Finland .Social Education. Social Pedagogy. Social Work. 


\section{Introduction}

Since the beginning of the conceptual history of social pedagogy, the term itself has been a challenge. The term was used first by German school politician Karl Mager in 1844, when he emphasized the importance of considering the connections of education to social reality in educational research and policies. Soon after, in the 1850s, another German scholar of education Adolph Diesterweg started to use the term combining the mission of education with social political interests. Before the turn of the $20^{\text {th }}$ century, several comprehensive systematizations of the concept inspired by different theories of human nature, moral philosophies, social theories, and epistemologies were displayed in the German debate around the concept (GOTTSCHALK, 2004). Since then, no consensus has been achieved but the multitude of interpretations has increased in both German and international debate.

Despite the multitude of interpretations, the need to clarify the concept was beneficial to the development of social pedagogy's self-understanding. From the very beginning, the need to make social pedagogical orientation theoretically understandable brought out a deep and rich academic debate around the term (RAUSCHENBACH, 1999. However, the multifaceted picture has also made it difficult to develop a consistent understanding of social pedagogy as a scientific discipline, a branch of studies, and a field of professional practice.

In the international context, social pedagogy has developed in the midst of different national policies and practices, theoretical traditions and philosophical schools of thought (HÄMÄLÄINEN, 2015). So far, the international debate around the concept has been mainly about introductions of country-specific constructions and interpretations. There are good reasons for meta-level analysis. Considering social pedagogy as an intellectual system consisting of research, theory-building and intellectual expertise, this presentation aims to provide the meta-level analysis with the necessary conceptual coordinates.

This paper is based on my previous publications dealing with aspects of social pedagogy such as the conceptual ambiguity of social pedagogy (HÄMÄLÄINEN 2012a; 2012b), the nature of social pedagogy as an academic discipline (Idem, 2003a), social pedagogical orientation in social 
work (HÄMÄLÄINEN, 2003b; 2018) and youth work (HÄMÄLÄINEN, 2012a), the ways of using the concept in Germany (MOSS, 2011) and Finland (HÄMALÄINEN, 2012c, 2014; HÄMÄLÄINEN; ERIKSSON 2015) as well as overviewing the field (HÄMÄLÄINEN; NIVALA, 2015), including semantic (HÄMÄLÄINEN, 2013b) and historical (HÄMÄLÄINEN, 2015) considerations. These publications are referred to only in the case where they provide relevant supplemental information.

In addition, other sources of information have been used, especially materials in which national traditions of social pedagogy and debates on its nature are introduced, compared, decoded and clarified (LORENZ, 2009; KORNBECK; ROSENDAL; CAMERON; MOSS, 2011). Methodologically this paper is based - mainly - on historical concept analysis.

\section{Social Pedagogy - an intellectual social system}

In fact the term social pedagogy has been used in many kinds of contexts referring to a particular academic discipline and a branch of studies, a field of professional activity, a set of educational methods, a tradition of educational philosophy, and even an entity of educational institutes. Often it is unclear in which sense the term is used. In some cases, there is more sentimental ideology than analytical conceptualization.

Historically social pedagogy has developed in relation to the process of modernization aiming to contribute to social drawbacks. Social problems such as poverty and child neglect were considered through a pedagogical lens (DOLLINGER, 2006). The early attempts to build a theory around the concept of social pedagogy and to answer to practical educational challenges caused by social change dealt with a new kind of discrepancy, that of the relationship between individual and society. Social pedagogy developed as an intellectual system to fulfill the pedagogical mission in a changing society shaped by transition of social structures in relation to modernization, industrialization, and urbanization.

The concept of social pedagogy originated in aspirations for educational theory building as an alternative to individualistic pedagogy, which was criticized for limiting itself to the processes of individual develop- 
ment. Social pedagogical theory building was driven by the questioning of philosophical anthropology and social ethics connected with issues of educational policy in the age of early modernization. The debate around the term created a tendency for educational philosophy to consist of different conceptions. The most significant early figures of social pedagogy were philosophers, for example the Germans Paul Natorp and Herman Nohl. There are still good reasons to regard social pedagogy as a direction of educational philosophy.

Social pedagogy is commonly characterized by attachment to social ethics and political interests. Over the course of time, the fundamentals of social pedagogy have been determined through these connections. Its political mission has been construed sometimes with regard to improving social justice, sometimes in terms of promoting democracy or social cohesion. Education has been seen an instrument of social progress and social pedagogy is distinguished as the theory and practice of political or citizenship education, or pedagogy for the disadvantaged.

As a tradition of educational thinking and action, social pedagogy addresses itself - in theory and practice - to the junction between individuals and society, examining pedagogical and political answers to promoting human growth with respect to social integration and emancipation. It discusses education from the point of view of the educational qualities of society aimed at desirable social improvement in the name of human dignity and corresponding social ethical principles.

In order to understand the development of social pedagogy as an intellectual social system it is important to pay attention to its capacity for internal scientific debate on its mission. This pertains to striving to define itself and argument over different definitions in light of practical educational issues, such as the need to improve educational policies and construct new educational institutions. Natorp even introduced social pedagogy as an essential paradigm shift in the philosophy of education necessary for justifiable social and political reforms. Thus, social pedagogy has developed as a combination of intellectual debate, theory-building, and practical social activity.

The nature of social pedagogy as an intellectual social system might be discussed analytically from different perspectives and synthetically in terms of a holistic perspective. Three key elements of such a system of so- 
cial pedagogy are a scientific discipline, a branch of academic studies, and a possible expertise relevant to professional practice. These may be called subsystems each carrying out a special function and forming an intellectual social system together. Within this system, the subsystems resonate with each other.

Within this framework, social pedagogy - as an intellectual system - manifests itself as a particular field of research, a constitution of curriculum for academic studies and a specific space of professional expertise applying to educational activities. The core of such an intellectual system is its capacity for intrinsic scientific debate and self-determination.

\section{Social Pedagogy - a scientific discipline}

Social pedagogy as an academic or a scientific discipline is a fundamental element of the intellectual system of social pedagogy, influencing the aims and contents of study programs as well as interpretations of the practical knowhow. As different concepts of human nature, society, morals, and knowledge have manifested themselves in social pedagogical theory building from the beginning, they also influence views on the nature of social pedagogy as a scientific discipline.

There are several fundamental questions concerning the nature of social pedagogy as a scientific discipline. One of them concerns social pedagogy's independence in relation to other disciplines such as psychology, sociology, social policy, and even the science of education in general. It is common to see social pedagogy as a relatively independent academic field with a profiling, questioning and theory building of its own, and a legacy of self-determination, but it has also been viewed as an interdisciplinary academic field without real disciplinary independence.

Any scientific discipline may not be fixed to only one epistemology, moral philosophy, social theory, or understanding of human nature. Science is an open forum for theoretical confrontations and criticism where one-sided dogmatic postulations are excluded. From this point of view, social pedagogy, in order to be a scientific discipline, cannot be based only on a certain philosophy of knowledge or ethical theory. Correspondingly, the academic curricula should be open to different epistemological views. 
For example, in the German tradition of social pedagogy, concerning its epistemological foundations, it has been approached on the basis of different philosophies of knowledge such as phenomenology, hermeneutics, Critical Theory, critical rationalism, and analytical empiricism (e.g. WOLLENWEBER, 1983). Each epistemology provides a particular view on the questioning of social pedagogy, including a distinct understanding of research, knowledge basis, and theory building.

It is common to consider social pedagogy as a discipline discussing education and human growth by regarding people in relation to social contexts. In this case, communities and even society in large are seen as subjects of education. In addition, it is normal to introduce social pedagogy as a discipline applied to educational help for people with different kinds of social needs, corresponding occupational activities and education for necessary professional expertise. Moreover, social pedagogy has been regarded as dealing with non-professional educational activities with respect to non-formal education in civil society too.

The scientific debate on the nature of social pedagogy as a scientific discipline and the necessary research and theory building takes place in the midst of different conceptions. Correspondingly, in academic studies of social pedagogy students should familiarize themselves at least with the main epistemological approaches and schools of thought as well as schools of ethics, social philosophies, and theories of human nature. For this part, social pedagogy is a similar discipline to any other. Open and critical debate is the only sustainable foundation of any scientific discipline.

In the light of other disciplines, it is easy to see how important open and critical debate around different conceptions and understandings is for the development of social pedagogy as an intellectual system. For example in psychology, research and theory building overlap within the context of competing theoretical understandings of the nature of psychology, its mission, and questioning. This concerns particular areas of psychology too. There is, for example, more than one significant theory of child development, which students of developmental psychology aim to learn.

In general, science is universal. Opposite to this, social pedagogy has developed, traditionally, in national contexts with nation-specific characters (LORENZ, 2009) and there is a huge variation of conceptions worldwide (ÚCAR, 2015). It is obvious that the development of social pedagogy 
as a scientific discipline both requires and promotes international cooperation. Moreover, it provides the international cooperation with common elements necessary for obtaining universal conceptions. Simultaneously it forwards scientific debate on the nature of social pedagogy as a branch of studies and the proficiency needed in professional practice.

\section{Social Pedagogy - a branch of academic studies}

A large number of study programs have been developed with different aims and contents around the concept of social pedagogy. Some differences are linked to country-specific factors but, in addition, there are program-specific emphases connected with political and professional intentions exemplifying different understandings of the mission of social pedagogy as a scientific discipline and a field of practice.

The basic question of development of social pedagogy as a branch of academic studies concerns the aims and content of a study program. What should be studied when studying social pedagogy? The answer depends on the conception of social pedagogy, how we understand the social pedagogical expertise and the knowledge basis needed.

As long as the understanding of the nature of social pedagogical expertise is unclear it is difficult to establish purposeful curricula. Correspondingly, appropriate elaboration of social pedagogical expertise provides curriculum planning with the relevant conceptual framework. Each definition of the aims and content of studies embodies some kind of understanding of the nature of social pedagogical expertise, while on the other hand this understanding reflects the understanding of the nature of social pedagogy as an educational philosophy and its mission as an intellectual structure in the prevailing society.

There have been several attempts to identify country-specific features of social pedagogy as a field of professional expertise. Usually these analyses have been carried out in the light of country-specific understandings of the nature of social pedagogy as a particular way of thinking. The aim has been to identify and describe the country-specific conception of social pedagogy and describe it as combination of a theoretical framework and the system of practical applications (HÄMÄLÄINEN; ÚCAR, 
2015). It is logical to see study programs embodying a country-specific view on the mission and the expertise needed therein but there can be notable variation of programs in a national context too.

Thus, the aims and content of academic study programs in social pedagogy are connected with the understandings of social pedagogy's theoretical foundations, most important schools of thought included, as well as with the vision of social pedagogical practice and the nature of professional expertise. The study programs embody the conception of social pedagogy as an intellectual system and aspire to familiarize students with theoretical foundations and practical applications of social pedagogical expertise. In this sense, study programs are always a function of the vision of the social pedagogical mission in practice and its theoretical basis, including the nature of the expertise needed.

\section{Social Pedagogy - a field of professional practice}

There is a lot of variation in using the concept of social pedagogy in relation to professional activities. This variation is connected with different philosophies of sciences, concepts of humans, and society, and political interests. As a particular social system, social pedagogy, in theory and practice, is shaped decisively by the social and political conditions where it takes place, country-specific welfare and education systems, in particular. From this point of view, historical considerations are necessary for analyzing such concepts as social pedagogy and social work, which have a national nature shaped by national social orders.

The development of social pedagogy as a professional practice is closely connected with its development as a field of professional education. The key question concerns the nature of social pedagogical expertise. This, for its part, embodies the conception of social pedagogy as a scientific discipline. Social pedagogy as an intellectual system consists of these three intertwining elements with reference to defining the characteristics of proficiency needed in social pedagogical practice.

Concerning the question of how social pedagogy relates to professional activities, the fundamental point seems to be that social pedagogy can be understood either in terms of a field of one profession, or in terms 
of many professions. In many countries, social pedagogy is regarded as a profession, which is more or less identical to the profession called social work. Opposite to this, social pedagogy has also been viewed as a discipline or theoretical framework for the multi-professional domain of social and educational activities. Social pedagogy has been introduced mainly with reference to popular education, community education, and social education. In addition, it has been viewed as a non-professional educational activity.

The professional knowledge and skills associated with social pedagogical practice do not differ essentially from practice skills needed in any other pedagogical work. Traditionally attention is paid to communication skills and dialogue based working methods in particular. This orientation is also essential in the effort to develop social pedagogy as a new paradigm of care and education work in the British Isles where the continental tradition of social pedagogy has resonated very little previously (e.g., CAMERON; MOSS, 2011). In addition, different theoretical frameworks for social pedagogical activities have been developed such as the "life world orientation" launched by Hans Thiersch and the "dialogue based improvement of people's social consciousness" by Paulo Freire and his followers.

In the following, different ways to define social pedagogy as a professional activity will be illustrated through examples from Germany and Finland. These two examples do not cover the variation of national policies and practices around the concept of social pedagogy in detail, not to mention different country-specific ways to use the term in the context of professional activities. However, they exemplify fundamentally different schools of thought regarding the understanding of social pedagogy as a professional practice.

\section{The German example}

From a historical point of view, it makes sense to remember that the first German scholars using the concept of social pedagogy around the mid-19 ${ }^{\text {th }}$ century, Karl Mager and Adolph Diesterweg, were school politicians who developed the concept of social pedagogy in and for school- 
ing contexts. Also those who aimed at social pedagogical theory building in Germany at the turn of the $19^{\text {th }}$ and $20^{\text {th }}$ century, Paul Natorp at the forefront, were at least mostly striving for a general theory of education without aspiring to professional reductionism. In the German tradition, the professional emphasis came to the picture later.

The German example is very important because, traditionally, Germany has had a leading position in theory building and in the use of the concept of social pedagogy worldwide. Many German scholars regard social pedagogy as a distinct German tradition, the canon of classics of social pedagogy included (IEMEYER, 2010). Nowadays the most common standpoint in Germany is to consider social pedagogy as a parallel concept to social work, as a synonym of it or a profession, which consists of both social pedagogy and social work and combines the titles of 'social worker' and 'social pedagogue'. Social pedagogy is viewed as and reduced to one profession in terms of either.

In Germany, the question of how social pedagogy and social work relate to each other has been discussed widely and thoroughly. Different logical alternatives have been identified and conceptualized. It seems that in every country where both concepts come into use it is necessary to deal with the question of their relationship. The theoretical classifications are very useful for systematic planning, for decision-making concerning the use of the concepts, and for identifying and comparing the designs in individual countries.

In one of the most advanced analyses of the relationship between social pedagogy and social work, four main classes have been outlined on the grounds of the knowledge basis, the theory-practice relationship, and the nature of practice activities (MÜHLUM, 1981):

1. Divergence: SP and SW are two different fields of activities whose knowledge bases and theoretical coordinates differ decisively from each other

2. Convergence: SP and SW have different scientific bases and theoretical roots, SP has germinated from educational sciences and SW from social political sciences, but they have come closer to each other and are intertwined in theory and practice through increasing interaction 
3. Substitute or subordination: SP is the upper concept and SW is either substituted by SP or subordinated to SP both theoretically and in practice

4. Subsuming: SP and SW have different scientific bases and theoretical roots but they have grown together, unified and become one in theory and in practice

The German debate on the relationship of social pedagogy and social work has benefited from this classification and corresponding considerations. Attention has been paid, for example, to the options to emphasize either the first part of both concepts, 'social', which leads to convergence, or the latter parts, 'pedagogy'/'work', which leads to divergence, or understands them as equal in terms of subsuming (MERTEN, 1998). However, the last alternative, subsuming, is the prevailing opinion among German scholars today, as it seems to be the tendency - more or less - also in many other countries (KORNBECK; ROSENDAL, 2009). The main trend in Germany is to equate social pedagogy with social work as a field of professional practice.

The implication of equating social pedagogy and social work has been to introduce and develop social pedagogy as a particular profession and a profession-specific scientific discipline even if with controversial stands and perspectives (NIEMEYER, 2003). Social pedagogy is seen as the theoretical framework and the field of practice for the activities of the profession called social work.

\section{The Finnish example}

In Finland, social pedagogy has been developed as a theoretical framework, generally speaking, for all social and educational professions. At university level, it has been introduced as an academic discipline between social and educational sciences. As a branch of research and academic education, social pedagogy has been viewed as a discipline combining social and educational issues in theory building and practice applications. Institutions of welfare and education are widely seen as potential contexts for social pedagogical expertise. The Finnish conception 
of social pedagogy is to be introduced in terms of interrelating dimensions of science, education, and field of practice (HÄMÄLÄINEN, 2012c), especially as a particular field of theoretical orientation and expertise relevant for several professions in the areas of welfare and educational work (HÄMÄLÄINEN, 2014). Attention is paid both to communal and individual aspects of education contributing to human growth.

The Finnish conception can be identified as an example of subordination concerning the question of how social pedagogy and social work are seen to relate to each other. As a discipline that contributes to many professions in the systems of welfare and education, social pedagogy is one branch of the multidisciplinary theory and knowledge basis of social work together with other social disciplines, especially social policy, social psychology, sociology, and social ethics. Not only does social work benefit from social pedagogy but rather social pedagogy is seen to provide conceptual and philosophical impacts to all professions dealing with welfare and education.

In the Finnish social order, welfare and education are traditionally linked closely together, which offers a good basis for developing social pedagogy as an integrative concept combining social and educational intentions and interests. The education system is essentially viewed through a social political lens in terms of contributing to welfare, social security, equality, and social justice - political values that Finnish social order is essentially based on. In the Finnish welfare system the health aspect plays an important role too. Social and health activities are administered by common public organs at all levels of administration. More than a quarter of qualified social workers are employed by health agencies.

In this context, social pedagogy has been developed as a field of expertise dealing extensively with different professional lines of social and educational activities. It has been stressed that social pedagogy is not a profession at all, but a particular area of expertise based on academic education; whereas social work, youth work and corresponding areas of work are professional fields in which professional qualifications are fixed by law and in which social pedagogical expertise is seen as relevant, are suitable areas for applying social pedagogical expertise.

In the Finnish debate, social pedagogy has sometimes been introduced as an approach or even a paradigm in social work but it has never 
been reduced to be subordinate to only social work. As a field of expertise, it has widely been seen to cover all kinds of welfare and educational work both in governmental organizations and in the fields of civic activities. Concerning doctoral dissertations social pedagogical expertise has been studied, for example, in terms of citizenship education (NIVALA, 2008), liberal education (NIEMELÄ, 2011), institutional care (KARPPINEN, 2018), and school welfare work (SIPILÄ-LÄHDEKORPI, 2004). It has been seen to offer opportunities for preventing and alleviating the social exclusion of young people, for example, in promoting children's and young people's schooling careers both in compulsory education (VILPPOLA, 2007 and in vocational education (KOMONEN, 2001). Social pedagogy has been viewed as a framework for tackling the social and individual problems caused by the collapse of socialization.

Within the educational system, social pedagogical expertise is seen to apply to both formal and non-formal education covering all age levels from early education to adult education. Institutions of liberal education, for example community colleges, folk high schools, summer universities, adult education centres, and sports institutes are one special field of social pedagogical expertise. In addition, many other public and non-governmental fields of the educational system, such as youth work, welfare work in schools, child day care, and residential care for children, have been seen as lines of activities in which social pedagogical expertise has relevance. Social pedagogical expertise has been seen to concern essentially social interactions in different life contexts.

\section{Conclusions}

There are good reasons to consider social pedagogy as an intellectual system consisting of the aspects of discipline, branch of studies, and practice applications with respect to possible professional expertise. All meaningful questions seem to drive the understanding of the nature of the mission of social pedagogy and the necessary intellectual instruments to fulfill it.

The outline of social pedagogy as an intellectual system provides the debate on the mission of social pedagogy with a holistic conception and 
demands sophisticated intellectual discourse. It helps to discuss individual questions systematically in relation to each other and comprehensively in the light of a general view. This kind of discourse in turn supports the fulfillment of the mission by furnishing it with relevant comprehensive ideas.

Let us think of, for example, the issue of whether social pedagogy should be viewed and developed as a discipline and a branch of studies for one profession, or as a field of expertise covering many professions? Research cannot answer this kind of question, but it can aim to weigh the pros and cons of both positions. The future of social pedagogy essentially depends on which forms of the nature of social pedagogy are followed. In order to answer such a question competently, attention must be paid to all the essential parts of social pedagogy as an intellectual system.

Regarding social pedagogy as an intellectual social system consisting of the elements of a scientific discipline, a branch of academic studies, and a field of professional practice, it is not without significance how the role of each of these aspects is understood to fulfill the mission of social pedagogy and the necessary expertise. Instead of examining the aspects separately, the system enables their analysis as a combination of intertwining elements shaping each other. As an intellectual system, social pedagogy aims to create a conscious and critical debate between different intellectual traditions and schools of thought. Each tradition has distinct consequences for the development of social pedagogy as an ordered social system.

The historical conceptual analysis reveals that the theoretical understanding of the nature of social pedagogy has significance for professional applications. Viewing social pedagogy as one profession brings essentially different forms of expertise and practical realizations. One concrete dimension is the variety of understanding of the relationship between social pedagogy and a particular professional field such as social work, youth work, early education, or health education. It is important to keep in mind that there are significant differences between national systems of professional titles.

Comparing country-specific traditions helps to find the key elements of different philosophies and the ways to think and act. However, it is rather difficult to explain the differences between country-specific understandings, policies, and practices. Each individual tradition has a 
history of its own shaped by country-specific social, political, economic, and cultural factors. Each interpretation is authorized by its own existence and history. It is a task of research to clear the nature of different traditions, policies, and practices.

The question of the nature of social pedagogical expertise comes to the fore in the debate on the nature of the mission. As far we understand social pedagogy in terms of the expertise that is needed at welfare and educational work in general, there are reasons to put the question about one profession or many professions in the form of how social pedagogy contributes to professional activities and what the expertise provides in terms of professional knowhow. This may not be only one profession but a much wider range of professions operating in different welfare and education organizations.

Moreover, it is conceivable to see and develop social pedagogy both as a particular profession and as a discipline potentially beneficial to other professions too. Psychology is an example of this kind of discipline.

\section{References}

CAMERON, C.; MOSS, P. (eds.) Social Pedagogy and Working with Children and Young People. Where Care and Education Meet. London and Philadelphia: Jessica Kingsley Publishers, 2011.

DOLLINGER, B. Die Pädagogik der Sozialen Frage. (Sozial-)Pädagogische Theorie vom Beginn des 19. Jahrhunderts bis zum Ende der Weimarer Republik. Wiesbaden: VS Verlag für Sozialwissenschaften. [Pedagogy of the social question. (Social) pedagogical theory from the beginning of the 19th century to the end of Weimar Republic], 2006.

GOTTSCHALK, G. M. Entstehung und Verwendung des Begriffs Sozialpädagogik. Extrapolation systematischer Kategorien als Beitrag für das Selbstverständnis heutiger Sozialpädagogik. Eichstätter Sozialpädagogische Arbeiten. Band 16. Eichstätt: diritto Publikationen, 2004.

HÄMÄLÄINEN, J. Developing social pedagogy as an academic discipline. In: A. Gustavsson \& H.-E. Hermansson \& J. Hämäläinen (eds.) Perspectives and Theory in Social Pedagogy. Göteborg: Daidalos, 2002a. p 133-153.

HÄMÄLÄINEN, J. The Concept of Social Pedagogy in the Field of Social Work. Journal of Social Work, London, Thousand Daks, CA and New Delhi: Sage. 2003, b. 3 (1), 69-80..DOI: 10.1177/1468017303003001005 
HÄMÄLÄINEN, J. Die deutsche Sozialpädagogik im Blickwinkel internationaler Rezeption. In: B. Dollinger \& M. Schabdach (Hrsg.) Zugänge zur Geschichte der Sozialpädagogik und Sozialarbeit. Siegen: Universitätsverlag Siegen. 2011. p. 223-235. [The German social pedagogy from the perspective of international reception].

HÄMÄLÄINEN, J. Developmental Psychology, Youth Sociology and Social Pedagogy - Three Perspectives on Youth Work and Youth Work Policy. In: F. Coussée, H. Williamson \& G. Verschelden (eds.) The History of Youth Work in Europe. Relevance for Today's Youth Work Policy. Strasbourg: Council of Europe Publishing. 2012 a. p. 93-104.

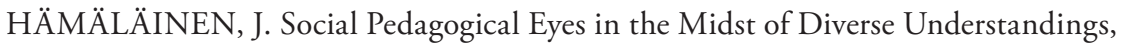
Conceptualisations and Activities. International Journal of Social Pedagogy. 2012b, 1 (1). p. 3-16.

HÄMÄLÄINEN, J. Social Pedagogy in Finland. Criminology \& Social Integration The International Journal of Social Pedagogy. 2012c. 20 (1). p. 95-104., 2012c.

HÄMÄLÄINEN, J. Vad gör pedagogiken “social”? - Använding av attributet "social” in begreppet socialpedagogik. In L. Eriksson, G. Nilsson \& L. A. Svensson (red.) Gemenskaper. Socialpedagogiska perspektiv. Göteborg: Daidalos. 2013b.

HÄMÄLÄINEN, J. Developing Social Pedagogy as an Academic Discipline and Professional Practice: Learning from the Finnish Experience. Journal of the Research on Lifelong Learning and Career Education. 2014. 10. p. 53-68.

HÄMÄLÄINEN, J. Defining Social Pedagogy: Historical, Theoretical and Practical Considerations. British Journal of Social Work2015. 45 (3). p. 1022-1038. doi:10.1093/ bjsw/bct174

HÄMÄLÄINEN, J.; ÚCAR, X. La pedagogía social en el mundo/Social Pedagogy in the world/Pedagogia Social no mundo. Pedagogía Social: Revista Interuniversitaria, No 27, 13-18. 2015. DOI: 10.7179/PSRI_2016.27.01.

HÄMÄLÄINEN, J. Social Pedagogy. In: Neil Thompson and Paul Stepney (eds.) Social Work Theory and Methods. The Essentials. New York and London: Routledge, 166-179, 2018.

HÄMÄLÄINEN, J.; NIVALA, E. Social Pedagogy. In Oxford Bibliographies in Education. Edited by Luanna H. Meyer. New York: Oxford University Press. DOI: 10.1093/OBO/9780199756810-0125, 2015. 
HÄMÄLÄINEN J.; ERIKSSON, L Social Pedagogy in Finland and Sweden: A comparative analysis / Pedagogía social en Finlandia y Suecia: Un análisis comparativo / A Pedagogia Social na Finlandia et Suécia: Uma análise comparativa. Pedagogía Social: Revista Interuniversitaria, No 27, 71-93. (DOI: 10.7179/PSRI_2016.27.01, 2015.

KARPPINEN, L. Lastenkotitoiminnan muotoutuminen Sisälähetysseuran Kasvattajaopistossa Ruusu Heinisen johtajatarkaudella 1918-1932. Aatepohja, pedagogiset painotukset ja ammatillisten käytäntöjen periaatteet Snellmania, Kuopio campus. [Formation of Children's Home Operation at Sisälähetysseuran Kasvattajaopisto (Educational College of the Inner Mission Society in the Church of Finland) during the term of office of Directress Ruusu Heininen from 1918 to 1932. Ideological basis, pedagogical emphases and principles of professional practices], 2018.

KOMONEN, K. Koulutusyhteiskunnan marginaalissa? Ammatillisen koulutuksen keskeyttäneiden nuorten yhteiskunnallinen osallisuus. University of Joensuu. [In the margin of education society? Social participation of young people cancelled their vocational schooling], 2001. 951-708-999-6 nidottu

KORNBECK, J.; ROSENDAL, J. N. (eds.) The Diversity of Social Pedagogy in Europe. Studies in Comparative Social Pedagogies and International Social Work and Social Policy. Volume VII. Bremen: Europäische Hochschulverlag, 2009.

KURKI, Leena; NIVALA Elina \& SIPILÄ-LÄHDEKORPI. Sosiaalipedagoginen sosiaalityö koulussa. Helsinki Pirkko: Finn Lectura, 2006.

LORENZ, W. Paradigms and Politics: Understanding Methods Paradigms in an Historical Context: The Case of Social Pedagogy British Journal of Social Work, 2009. 38 (4). p. 625-644.

MERTEN, R. (Hrsg.). Sozialarbeit - Sozialpädagogik - Soziale Arbeit. Begriffsbestimmungen in einer unübersichtlichen Welt. Freiburg im Breisgau: Lambertus. [Social work - social pedagogy - socially oriented work. Conceptual definitions in a indistinct world], 1998.

MÜHLUM, A Sozialpädagogik und Sozialarbeit. Eine vergleichende Darstellung zu der Bestimmung ihres Verhältnisses in historischer, berufspraktischer und theoretischer Perspektive. Frankfurt am Main: Eigenverlag des deutschen Vereins für öffentliche und private Fürsorge. [Social pedagogy and social work. A comparative description and definition of their relationships from historical, occupation-practical and theoretical perspective], 1981.

NIEMELÄ, S. Sivistyminen. Sivistystarve, -pedagogiikka ja -politiikka pohjoismaisessa kansansivistystraditiossa. Snellman-instituutin A-sarja 25/2011. Keuruu. [Bildung. Civilization need, pedagogy and policy in the Nordic tradition of popular education], 2011. 
NIEMEYER, C. Sozialpädagogik als Wissenschaft und Profession. Grundlagen, Kontroversen, Perspektiven. Weinheim und München: Juventa Verlag. [Social pedagogy as science and profession. Foundations, controversies, perspectives], 2003.

NIEMEYER, C. Klassiker der Sozialpädagogik: Einführung in die Theoriegeschichte einer Wissenschaft. 3., aktualisierte Auflage. Weinheim und München: Juventa Verlag. [Classics of social pedagogy], 2010.

NIVALA, E. Kansalaiskasvatus globaalin ajan hyvinvointiyhteiskunnassa.

Kansalaiskasvatuksen sosiaalipedagoginen teoriakehys. N. Snellman-instituutti A-sarja 24/2008. Kuopio. [Citizenship education in the welfare society of the global age. Social pedagogical framework for citizenship education], 2008.

RAUSCHENBACH, T. Das sozialpädagogische Jahrhundert: Analysen zur Entwicklung Sozialer Arbeit in der Moderne. München: Juventa. [The social pedagogical century: Analyses of development of social work in the modern], 1999.

SIPILÄ-LÄHDEKORPI, P. “Hirveesti tekijänsä näköistä”. Koulukuraatorin työ peruskoulun yläasteella. Helsinki: Oy Finn Lectura Ab. ["It's a lot like a person who does it" The work of a school social worker in the upper level of comprehensive school]. 2004

VILPPOLA, T. Reaalipedagoginen toimintaprosessi-sosiaalipedagogisen työn sovellus koulutuksesta syrjäytymässä olevien nuorten kokonaisvaltaisessa tukemisessa. Acta Universitatis Ouluensis E 88. Oulu. [The real-life-oriented pedagogical action process - an application of social pedagogical work to comprehensively support young people threatened by exclusion from education], 2007.

WOLLENWEBER, H. (Hrsg.) Modelle sozialpädagogischer Theoriebildung. Paderborn: Ferdinand Schöningh. [Models of social pedagogical theory building], 1983.

Recebido em 26 fev. 2019 / Aprovado em 10 mar. 2019

Para referenciar este texto:

HÄMÄLÄINEN, J. Social Pedagogy as a Scientific Discipline - a Branch of Academic Studies and a Field of Professional Practice. EccoS - Revista Científica, São Paulo, n. 48, p. 17-34. jan./mar. 2019. Disponível em: <https://doi.org/10.5585/ EccoS.n48.12393>. 